\title{
The Art of Caucaseco: An Afro-Colombian Fight Book
}

\author{
T.J. Desch-Obi \\ Department of History, City University of New York \\ profobi@gmail.com
}

\begin{abstract}
While most fight books were presumably written by elites or sociallyhonoured martial classes, this article will explore a fight book of an AfroColombian martial arts style that emerged just six years after the abolition of slavery. The Afro-Colombian martial arts of grima emerged in the Cauca region during the era of slavery and trained its exponents to fight using the machete, azagaya, or unarmed body as weapons. Over the course of the second half of the nineteenth century, grima began to proliferate into over thirty unique styles, each with its own special choreographies and approaches to combat. As these styles multiplied, so too did the literary genre of grima manuscripts called cartillas de malicia, which recorded each style's techniques, pedagogy, and lineage. This article explores the historical context and purpose of a single cartilla de malicia in the grima style. This cartilla de malicia was of a style from the Caucaseco region of the Cauca, which was developed in 1858 and existed for well over a century.
\end{abstract}

Keywords: Colombia, Cartilla de malicia, grima, azagaya, fight book.

\section{INTRODUCTION}

While most fight books were presumably written by elites or socially-honoured martial classes, this article will explore a fight book of an Afro-Colombian martial arts style that emerged just six years after the abolition of slavery in the region. The specific fighting style contained in this manuscript, provisionally called Caucaseco, was one of more than thirty martial arts styles known collectively as grima that were practiced well into the midtwentieth century. The epicentre of grima was the Colombian Cauca region. AfroCaucanos (people of African descent in the Cauca) began developing the foundational grima styles during the era of slavery. These martial arts trained exponents to fight using the machete, azagaya, stick, or unarmed body as weapons. The foundational styles of grima were based upon African diaspora principles of combat, particularly corporal dexterity and malicia (stratagem/cunning). Grima manuscripts were themselves referred to as cartillas de malicia (books of stratagem), or just cartillas for short. This brief reflection on the Caucaseco cartilla de malica will explore the historical context of the art and then consider the purpose of such fight books. 


\section{THE CAUCASECO CARTILLA DE MALICA: AN OVERVIEW OF ITS CONTENTS}

The cover page of the only existent Caucaseco cartilla de malica manuscript is missing, leaving the name of the grima style and its founder uncertain. ${ }^{1}$ Until further information comes to light, the art can be referred to simply as Caucaseco, after the area in which it was both developed and maintained from 1858 until the mid-twentieth century. The seventy-two page manuscript is divided into five sections. The first section is a single page that provides an overview of the weapon positions for the start of each educational choreography which makes up the core of the cartilla. This starting position is referred to as a parada. Somewhat akin to a guard position in European fencing, these paradas were formed by the player's stance and manner of holding their weapons before initiating a cruza, a two-person educational choreography that formed the core of grima education. This overview section shows each parada position in a shorthand sketch, allowing for quick reference.

The second section of the manuscript (fig. 1), entitled "Juego Sencillo" ("simple game"), numbers, names, and illustrates the first thirty lessons of the system. Eight of these illustrations represent footwork patterns, or the context in which the lesson is to be applied. For example, lesson fourteen depicts a training exercise to help stiff students acquire flexibility, and lesson twenty-two illustrates a greeting on the street being received with caution. The majority of lessons, however, depict the parada opening positions that initiate two-person educational choreographies of attacks and defences in which the players are armed with a single weapon. The third section of the manuscript, entitled "Juego Doble" ("double game") continues to cover more cruzas and their opening paradas, but in these choreographies each player uses of two or more weapons. The fourth section, entitled "Paradas Sueltas" ("Separate Paradas"), numbers, names, and illustrates additional paradas and cruzas.

The fifth and final section (fig. 2) is the hand-written explanation for each of the previous three sections. These explanations cover the attacks and defences contained in each cruza choreography, drills to develop dexterity and flexibly, as well as advice on the ideal characteristics of an exponent of the system. The explanations and advice regarding specific situations make this and similar cartillas de malicia important historical resources when read in light of the larger historical and ethnographic context.

\footnotetext{
1 The fact that this manuscript was maintained at all is thanks to Cesar Lenis who was wise enough to go against the established tradition of burning a master's books upon his death.
} 


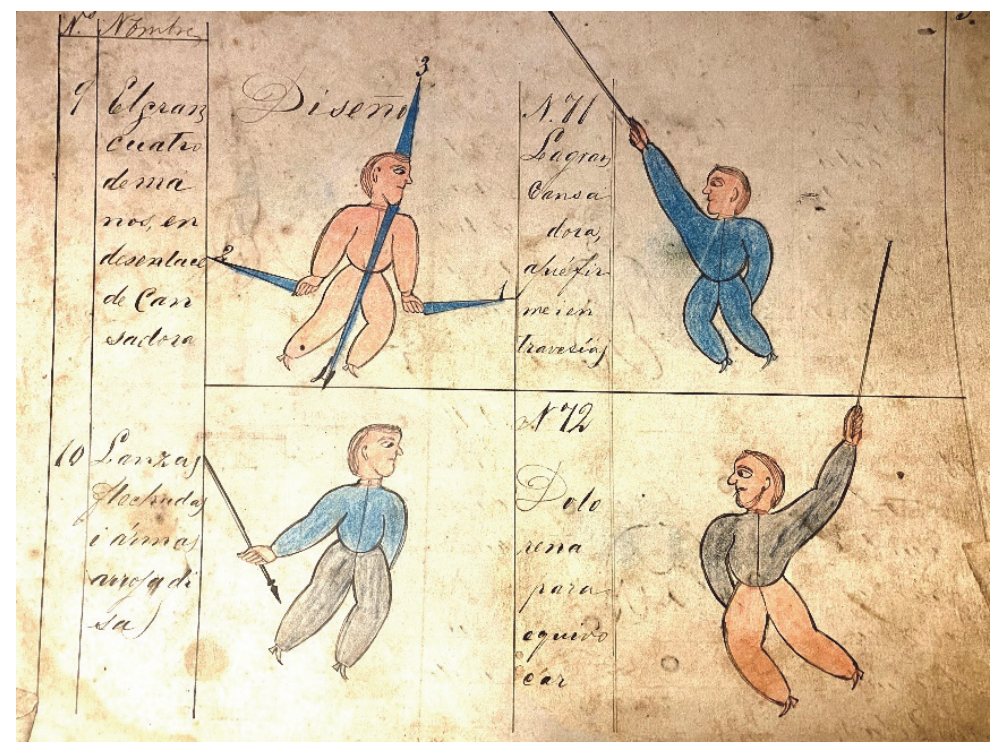

Fig. 1: Name and illustration of the fighting techniques. Anonymous, Caucaseco cartilla de malica, [1875], fol. 3

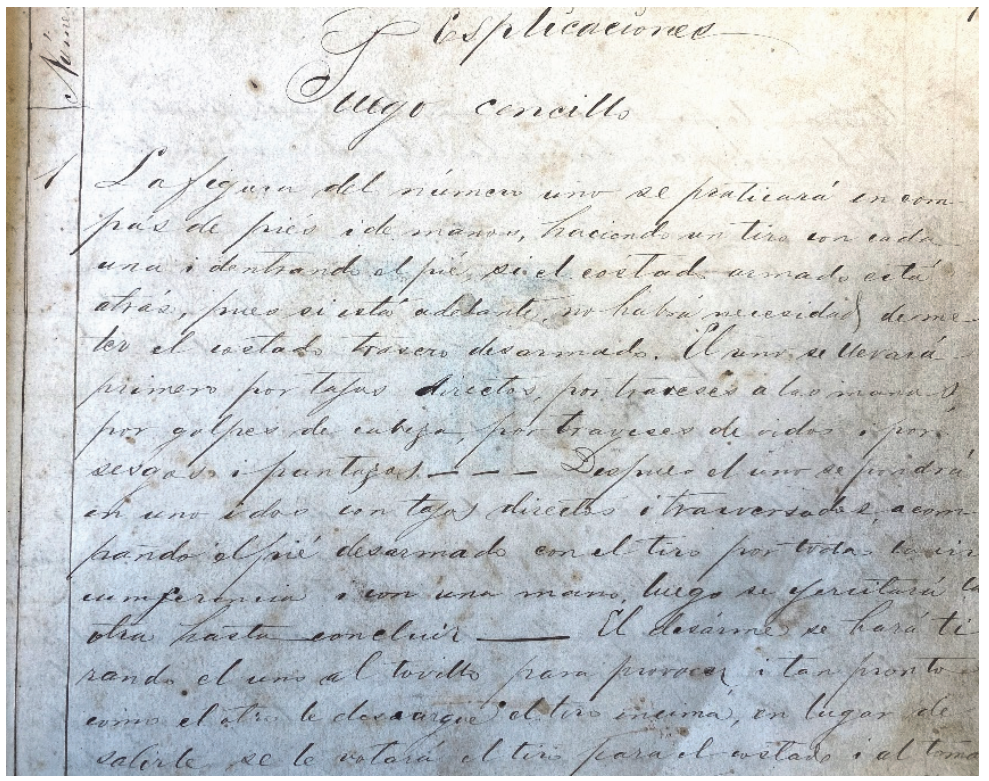

Fig. 2: Written commentary related to the illustration of the fighting techniques. Anonymous, Caucaseco cartilla de malica, [1875], fol. 14 


\section{THE CONTEXT AND ORIGINS OF CAUCASECO}

The existent cartilla reveals multiple layers of accretion corresponding to the lives of three distinct masters: the style's founder, this cartilla's author, who was a man by the name of Manuel Cardenas, and Agapito Lenis, the master who taught with the manuscript into the twentieth century. The first strata of formation of this cartilla de malicia was the core of the art as described in sections two and three. This material was established by the style's founder in 1858. Internal textual evidence suggests master Nuñez may have been the style's founder as he receives the most strikingly detailed portrait. While the founder's biographical details are unclear, the dating, location, and contents of the style suggests something about the process leading to the style's foundation.

The decade preceding the foundation of this grima style had been socially tumultuous. In 1849 Liberal leader José Hilario López won the presidency in a questionable victory due to Congress being attacked by a liberal mob. A year later in 1850, Afro-Caucanos from the countryside began streaming into the urban areas during an uprising in which they turned their fighting sticks against the upper classes in protest against greed and called for abolition, among other reforms. This helped usher in the legal enactment of abolition in Colombia that came into effect in January 1852. After the announcement of the upcoming abolition, the Conservatives in the Cauca region responded by rising up in rebellion in order to take political power from the Liberal government and re-establish slavery. AfroCaucanos flocked to the Liberal ranks and massively outnumbered the Conservative forces, quashing the rebellion and thus ensuring an end to slavery in Colombia. ${ }^{2}$

In the 1853 elections the Liberal candidate, José María Obando, gained the presidency, yet Conservatives in the Cauca won a growing series of victories. State governors, who had previously been appointed by the president, had to be elected locally under the new 1853 constitution. Conservatives took control of many provinces in the Cauca and across the country in these local elections. Even in the Liberal stronghold of Cali, two Liberals running against each other led to a Conservative victory. Liberal divisions would soon lead to another Conservative victory on a national level. Two camps emerged among the Liberals in the capital of Bogotá. One of these was the Gólgotas, elites who adhered to strict economic liberalism, but the other camp, the Draconianos, were in favour of tariffs on trade. A combination of local Conservative victories in the 1853 elections, the declining influence of the military, and support among Bogotás artisans inspired Draconiano General José María Melo into revolt the following year. The revolt called for a rejection of the 1853 constitution and for Obando to rule the state directly. President Obando refused to publicly support this revolt and many Gólgotas joined with the Conservatives to form the Constitutionalists in order to defeat what they saw as a dangerous lower-class uprising.

As conflicting reports reached the Cauca, Liberals were unsure who to back. Ex-president José Hilario López, the symbol of national liberalism, denounced the Melo revolt. However, events that had no direct ties to the capital led to local uprisings in the Cauca.

2 Sanders, Contentious Republicans; Llano, 'La guerra de 1851', pp. 37-57. 
Local Indios (Native Americans) troops, now allied to the Conservatives, joined the Constitutionalists and violently crushed the Liberal rebels in the Cauca. Conservatives took advantage of the chaos by removing many Liberals from office and taking vengeance against Afro-Caucanos for the assaults in 1850. Many Afro-Caucanos, even prisoners of war, were killed and the brutal Conservative commander Manuel Tejada led a division tasked with hunting down the remaining rebels. The area of Caucaseco became one of a handful of refuges for these Afro-Caucano military groups that now found themselves criminalised by the state. ${ }^{3}$ These Liberal ex-combatants were mostly of African descent and local Conservative elites and government officials referred to them as malhechores (malefactors, or outlaws). ${ }^{4}$

The dating and location of this grima style's emergence seem to associate it with these Afro-Caucano Liberal combatants who were based in Caucaseco after the failed 1854 Melo Revolt. While active hostilities came to an end with the Conservative assaults on the rebels in 1855, the area remained a base of operations for Afro-Caucano Liberal forces until they joined the 1859 revolution that put Cauca's Liberal leader, Tomás Mosquera, in power nationally. ${ }^{5}$ Between these two revolts, the rebel Liberal refuge of Caucaseco would have housed an unusually high concentration of grima exponents of various styles in close proximity. Such practitioners were bound by common ideals, thus providing the ideal conditions for cross-fertilisation and the creation of a new hybrid style.

A stylistic analysis of the technical elements contained in the Caucaseco cartilla reveal that at least two distinct styles were integrated in the creation of this new style. The first of these two original styles was Relancino. As with the other foundational grima styles, Relancino dates back well into the era of slavery and was built upon African Diaspora combat traditions. Like other African diaspora martial arts, it utilised corporal movements and crouching for defence, and malicia for offense on strategic and tactical levels. Distinct from many other grima styles, Relancino emphasised the use of the azagaya, an African weapon famed for its use as both a thrusting and a missile weapon. In the West African Sahel region, this was the primary battlefield weapon of equestrian elites who trained from their youth in its use along with swordsmanship. When leadership duels were fought on the battlefield, it was primarily with the azagaya, which was also found throughout most of the African continent. ${ }^{6}$ The azagaya was incorporated along with a bladed weapon (a machete or sword) as the central weapon combination in the art of Caucaseco. The Caucaseco azagaya appears in three distinct lengths and shapes in the illustrations of this cartilla de malicia. This weapon was used to throw, stab, and even slash in this form of grima. This azagaya work provided a lethal efficiency that allowed Caucaseco to retain its battlefield utility.

${ }^{3}$ Bosch, Reseña Histórica de los Principales Acontecimiento Políticos de la Ciudad de Cali.

${ }^{4}$ Díaz Casas, Salteadores y cuadrillas de malhechores.

${ }^{5}$ Bosch, Reseña Histórica; Llano, Entre la resistencia social, pp. 60-61.

${ }^{6}$ For a more detailed exploration of the azagaya in Africa and Colombia, see Desch-Obi, Hombres $y$ Mujeres Históricos. 
The second art that was a direct influence upon Caucaseco was Español, which represented a new type of grima; one played erect and at long range. Español, the first of a series of erect styles, emerged at the middle of the century from one of the foundational grima styles but added a number of innovations. Some of these innovations were purportedly inspired by a French épée fencing treatise. Yet Español's most important innovations derived rather from elements that existed in a nascent form in the foundational grima styles. One of these was the systematisation of paradas throughout the style. While the foundational group of grima styles had parada positions and had educational choreographies beginning in such positions, in Español this was systematised so that each choreography had its own opening parada position. The Caucaseco style incorporated this systemised parada approach to grima along with a number of parada choreographies themselves.

The manuscript described in this article was an expanded "second edition" written in 1875 by grima master Manuel Cardenas. It appears that this was a replica of the contents of the original cartilla, but with the addition of the material in the section entitled "Paradas Sueltas" (Separate Paradas). These were an additional twenty educational paradas that were added to the cartilla de malicia after its formal foundation. Yet these new paradas were only considered supplementary, and not part of the art's central curriculum. The cartilla was given to master Agapito Lenis, who continued in the tradition of Manuel Cardenas. During the last of the nineteenth-century civil wars, the War of a Thousand Days, master Lenis clandestinely acted as a messenger for the Liberal forces. Publicly however, he converted his home into a hospital for the war wounded of both sides. After the war, his house continued to serve as a respected grima academy in the region for decades into the twentieth century. After his death, the cartilla was fortuitously saved by his grandson, Cesar Lenis. While this cartilla de malica is an exceptional manuscript that existed without a living exponent, most other styles still have living exponents who are the sole owners of these private manuscripts.

\section{THE PURPOSE OF THE TEXT}

This Cacuaseco cartilla de malicia helps illuminate the purpose of this genre of fight books. The very fact that these manuscripts existed, despite the low levels of literacy among nineteenth-century Colombians in general, and Afro-Cacuanos in particular, attests to the perceived importance of this genre. During the first decades of independence there were efforts to improve primary level education in Colombia. After this initial push, school enrolments stagnated until the 1870 s when the government again pushed to increase both primary and tertiary levels of education. ${ }^{7}$ Yet, Colombia's percentage of primary education enrolment of $2.6 \%$ was still only half of the average in Latin America in $1900 .{ }^{8}$ One can only imagine that with Colombia's overall literacy rates being so low prior to 1900 , the

\footnotetext{
7 Only by 1925 did Colombia's overall literacy rate reach the Latin American average of 48\%.
} Safford, The Ideal of the Practical: Colombia's Struggle to Form a Technical Elite, pp. 49-79.

8 Posada-Carbó, 'Newspapers, Politics, and Elections in Colombia, 1830-1930’, pp. 944-45. 
literacy rates among Afro-Colombians in the first few generations after abolition were significantly lower. Countries like Venezuela, Argentina, and Cuba had parallel martial arts traditions and the latter two, at least, had much higher levels of literacy. None of the martial arts of those countries, however, appear to have developed a literary tradition. Set against this backdrop, the establishment of a literary genre such as cartillas de malicia among Afro-Colombians is both surprising and significant.

Despite - or perhaps in part because of this low literacy rate - cartillas de malicia served fundamentally as badges of authority. The testimony of students of such illiterate masters from the late nineteenth and early twentieth century makes clear that they prized their cartillas primarily as a diploma and certification of their credentials as a confirmed master. ${ }^{9}$ Of course, the cartillas de malicia were also so much more than this.

Cartillas de malicia were - as their name implies - important as repositories of malicia strategies. The Caucaseco cartilla passes on the art's philosophy of what characteristics made for a successful grima exponent, the importance of malicia, and the components of malicia in general. Malicia is an African diaspora philosophy and grand strategy that teaches the socially or physically weak how to resist the strong. The Caucaseco cartilla also shows how these malicia strategies of the ideal grima exponent can be applied to more concrete situations. This includes strategies for how to greet people in the street, how to safely apprehend criminals, and what to do in case of a house fire. The cartillas also pass on a pedagogical system based on the ability to express malicia on the technical and tactical level of armed and unarmed combat. These systems were integrated into the various educational choreographies that formed the bulk of the cartilla. Thus, cartillas fundamentally recorded the details of this pedagogy for clear transmission to future generations, and ultimately served as compendiums of malicia on technical, tactical, and strategic levels.

Cartillas de malica further recorded the lineage history of the art and how it should be taught. The Caucaseco cartilla begins with the date of the creation of the style, and names important masters in the system, including the author of the revised cartilla. The illustrations of the cartilla include portraits of some of these important figures, especially one that is likely the founder of the system. Other cartillas of this genre of grima styles list all the past and contemporary masters of the style. Additionally, cartillas de malicia advised the new master what and how to teach.

Scholars of fight books in Europe without living traditions have at times questioned if their manuscripts were meant as educational guides to learn from, or as repositories to aid a master's teaching. In the case of the Colombian cartillas de malicia, however, it is clear that these were meant only for masters, which is made clear from both ethnographic and textual evidence. Some grima masters may have brought their cartillas de malicia to training sessions, but never allowed students to look through them. In the case of the Caucaseco cartilla, the purpose of the first existent page clearly served this purpose. It allowed the

${ }^{9}$ Master Arturo Soto, interviewed by T.J Desch-Obi. 
master to set down the cartilla open to this page for a visual overview of the art and as a reference for the starting positions of each parada. Students who had not read the rest of the cartilla would not be able to glean any information from this page. Most masters, however, never even let their students see their opened cartillas. Only if they completed their training, and passed a graduation exam, would the students deemed worthy to act as masters be given a copy of the master's cartilla. In the case of the many illiterate masters of the late nineteenth and early twentieth centuries, they would contract scriveners and artists to write out and illustrate the handwritten manuscripts that would be given to the cohort of new masters. In a few cases these cartillas were personalised for each future master. The Caucaseco cartilla was clearly designed for teachers rather than students because it was addressed to the master of the art. Cartiallas de malicia frequently advised masters what paradas to teach to student and how much to charge for them. All grima masters admitted students who were willing to pay the complete tuition fee to learn the entire style but some masters also allowed some students to pay only per parada that they wanted. Further, the Caucaseco manuscript clearly teaches which paradas not to teach at all: "Do not teach this one to your students". This was itself a malicia so that if a student ever challenged the master, or had to be reprimanded for breaking the style's ethical code, the master had an arsenal of tactics of which the student was unaware. Thus, cartillas documented lineage histories and advised masters how and what to teach.

Many of these functions were not completely dependent upon literacy, as evidenced in the striking visuals of the Caucaseco cartilla. For example, portraits of past masters could serve as visual representations of lineage's history. Similarly, the images of paradas, footwork patterns, or combat situations all served as mnemonic devices that could aid even illiterate masters in the recalling of the style's choreographies, techniques, and malicias.

\section{CONCLUSIONS}

Colombian cartillas de malicia were a genre of fight book not made by elites or warrior classes, but by former slaves and their descendants. This genre emerged sometime during the era of slavery and continued until the mid-twentieth century. The art of Caucaseco emerged within a decade of abolition and was one of many new styles of grima developed in the second half of the nineteenth century. Grima masters like Miguel Cardona and Agapito Lenis cherished their cartillas, which were an important resource for grima masters even if they were personally illiterate. Despite low levels of literacy among AfroCaucanos, these literary texts served multiple functions: they documented the lineage's history and pedagogy; they conveyed individualised recommendations on how and what to teach as masters; most importantly, however, they served as certifications of legitimacy for a master of arms and repositories of the malicia strategies that helped Afro-Caucanos navigate a range of life challenges. 


\section{BIBLIOGRAPHY}

\section{VI.1. Primary sources}

Anonymous, Caucaseco cartilla de malica, [1875].

Bosch, Manuel Joaquín, Reseña Histórica de los Principales Acontecimiento Politicos de la Ciudad de Cali desde el Año de 1848 hasta el de 1855 inclusive (Imprenta de Echeverria

Hermanos: Bogotá, 1856)

Soto, Arturo, Master, interviewed by T.J. Desch-Obi, 2019, (08/05/2019)

\section{VI.2. Secondary literature}

Desch-Obi, T.J., Hombres y Mujeres Históricos (forthcoming)

Díaz Casas, María Camila, Salteadores y cuadrillas de malhechores: Una aproximación a la acción colectiva de la 'población negra' en el suroccidente de la Nueva Granada, 1840-1851 (Popayán: Universidad del Cauca, 2015)

Llano, Alonso Valencia, Entre la resistencia social y la acción politica: de bandidos a politicos (Cali: Universidad del Valle, 2014)

Llano, Alonso Valencia, 'La guerra de 1851', in Las guerras civiles desde 1830 y su proyección en el Siglo XX, ed. by Museo Nacional de Colombia (Bogotá: Museo Nacional de Colombia, 1998), pp. 37-57

Posada-Carbó, Eduardo, 'Newspapers, Politics, and Elections in Colombia, 1830-1930', The Historical Journal, 53/4 (2010), 939-62

Safford, Frank, The Ideal of the Practical, Colombia's Struggle to Form a Technical Elite (Austin: University of Texas Press, 1976)

Sanders, James E., Contentious Republicans: Popular Politics, Race, and Class in NineteenthCentury Colombia (Durham: Duke University Press, 2004) 